\title{
Has Oxidative Stress any Role on Mechanisms of Aminophylline - Induced Seizures? An Animal Study
} Roy UK,, ${ }^{1}$ Pal M, ${ }^{2}$ Datta $S,{ }^{2}$ Harlalka S ${ }^{1}$

\author{
${ }^{1}$ Department of Pharmacology \\ Burdwan Medical College, \\ Burdwan, WB, India, Pin-713104 \\ ${ }^{2}$ Department of Biochemistry \\ Burdwan Medical College, \\ Burdwan, WB, India, Pin-713104
}

\section{Corresponding Author}

Mirnal Pal

Department of Biochemistry

Burdwan Medical College,

Burdwan, WB, India, Pin-713104

E-mail: mrinalpal77@rediffmail.com

\section{Citation}

Roy UK, Pal M, Datta S, Harlalka S. Has Oxidative Stress any Role on Mechanisms of Aminophylline Induced Seizures? An Animal Study. Kathmandu Univ Med J 2014;48(4):269-74.

\section{ABSTRACT \\ Background}

Aminophylline can trigger seizures in patients without known underlying epilepsy or added risk factor for seizure exacerbation in epilepsy. Most of these seizures are difficult to control and are underappreciated compared to other drug toxicities. Despite a long clinical history of aminophylline-induced seizures, relatively little is known about the underlying molecular mechanisms that contribute to methylxanthine-induced seizure generation.

\section{Objective}

The present study evaluated the possible involvement of free radicals in aminophylline induced seizures in rat.

\section{Method}

The rats were divided into two groups. The first group graded single doses of aminophylline from 100 to $300 \mathrm{mg} / \mathrm{kg}$ were administered intraperitoneally. On the basis of the results Aminophylline, a dose $(300 \mathrm{mg} / \mathrm{kg}$ ) producing tonic-clonic seizures and mortality in $100 \%$ animals was selected as control in the study. The second group were subjected to single antioxidant (Vitamin E or Vitamin C) or in combination for 45 days then single doses of aminophylline $300 \mathrm{mg} / \mathrm{kg}$ administered intraperitoneally to rats.

\section{Result}

Aminophylline induced convulsions in rats in a dose-dependent manner, and both incidence of seizure and mortality were maximum at $300 \mathrm{mg} / \mathrm{kg}$ and there was significant increase of free radical generation. But though pre-treatment with antioxidants showed differential attenuating effects on aminophylline induced free radical generation as we all known but they were very much ineffective in antagonizing aminophylline induced seizures and post-seizure mortality by any appreciable extent.

\section{Conclusion}

Though Aminophylline induces oxidative stress the results are suggestive that at least free radicals is not only cause of convulsiogenic effects and post-seizure mortality of aminophylline.

\section{KEY WORDS}

Aminophylline, antioxidant, oxidative stress, seizures. 


\section{INTRODUCTION}

Aminophylline, a mixture of theophylline and ethylenediamine (85:15), is a bronchodilatating and antiasthmatic compound widely used in the treatment of bronchial asthma and chronic obstructive pulmonary disease. ${ }^{1}$ However, in view of its narrow therapeutic index it still has a reasonably high toxicity potential. ${ }^{2} \mathrm{~A}$ serious complication associated with intravenous aminophylline therapy for bronchial asthma is convulsions. Such seizures are usually not preceded by any prior milder and warning symptoms and are relatively refractory to conventional anticonvulsant agents. ${ }^{3}$ These repetitive, generalized seizures are commonly fatal and no specific, pharmacologically antagonistic drug is known. ${ }^{4}$ In an attempt to evaluate the mechanisms involved in this phenomenon, several studies have been implicated for one or the other mode of action, ${ }^{5,6}$ but no clear-cut consensus regarding the toxicodynamics of theophylline-induced seizures has emerged.

Recently, free radicals have been implicated in many drug and chemical induced toxicities. ${ }^{7,8}$ The central nervous system is highly susceptible to oxidative stress. Vulnerability of brain to oxidative stress induced by oxygen free radicals seems to be due to the fact that on one hand, the brain utilizes about one fifth of total oxygen demand of body for oxidative phosphorylation to acquiring energy as compare to other cells, on other because of its relatively small antioxidant capacity they cannot neutralized the toxic effect of free radicals. ${ }^{9}$ One recent study suggest that oxidative stress induced by free radical generation contributes to aminophylline seizures, ${ }^{10}$ but as aminophylline has antioxidant effects due to its phosphodiesterase inhibitory properties in human neutrophils the present experimental study was designed to review the possible role of reactive oxygen species (ROS) in the convulsiogenic effects of theophylline in rat model. ${ }^{11-13}$

\section{METHODS}

\section{Study area}

The present study was an animal model based case control study undertaken in the departments of Biochemistry with the collaboration of the department of Pharmacology of Burdwan Medical College, Burdwan, West Bengal, India.

\section{Animal}

Male Wistar strain albino rats (Rattus norvegicus albinus), between 1 to 2 months of age weighing $150 \pm 12 \mathrm{~g}, \mathrm{n}=$ 70 were obtained from the appropriately maintained institutional animal house. The rats had free access to drinking water and rat food pellets. The light source in the animal room was regulated with $12 \mathrm{hr}$ light period followed by $12 \mathrm{~h}$ dark schedule within a temperature of range of 22 to $\pm 2{ }^{\circ} \mathrm{C}$ at a relative humidity of 45 to $50 \%$. All rats were acclimatized for at least 7 days before induction of diabetes. All procedures involving animals were performed in accordance with the 'Guide for the Care and Use of Laboratory Animals (1985), NIH, Bethesda' and 'Guidelines for care and use of animals in scientific research' by the Indian National Science Academy (INSA), New Delhi, India. The study was approved and permitted by the institutional ethics committee for care and use of laboratory animals, and started after obtaining the written consent from the concerned ethics committee [Memo No. BMC/2179/1 (3)].

\section{Study design}

The animals had free access to food and drinking water till the day of start of the experiment. In the experiment, the rats were divided into two groups.

Group 1 rats $(n=28)$

a) Group la Aminophylline-induced convulsions ( $n=21$ ) $3 / 4$ Experiments were carried out with graded single doses of aminophylline from 100 to $300 \mathrm{mg} / \mathrm{kg}$ administered intraperitoneally to rats and subsequently put into individual perspex cages $(25 \times 25 \times 10 \mathrm{~cm}) .{ }^{10}$ The rats were then observed for $60 \mathrm{~min}(1 \mathrm{hr})$, and studied - (a) Percent incidence of seizures (animals showing atleast clonic seizures of forelimbs were taken for calculating \% incidence of seizures); and (b) Per cent mortality within 1 and $24 \mathrm{hr}$. All experiments were carried out in a quiet room between 10 AM and 3 PM (with constant light condition). On the basis of the results obtained with various doses of aminophylline, a dose $(300 \mathrm{mg} / \mathrm{kg}$ ) producing tonic-clonic seizures and mortality in $100 \%$ animals was selected for subsequent experiments to investigate the modulatory effects of different drugs influencing prooxidant/antioxidant balance and this group serves as control in the study.

b) Group Ib They $(n=7)$ were served as the control

All the rats in this group then were sacrificed by cervical dislocation.

Group 1 rats $(n=42)$

a) Group Ila - The rats $(n=7)$ in the group were subjected to normal diet containing vitamin E with the dose of $20 \mathrm{mg} /$ $\mathrm{kg}$ for 45 days then single doses of aminophylline $300 \mathrm{mg} /$ $\mathrm{kg}$ administered intraperitoneally to rats and subsequently put into individual perspex cages $(25 \times 25 \times 10 \mathrm{~cm})$. The rats were then observed as same way as Group I rats.

b) Group IIb - The rats $(n=7)$ in the group were subjected to normal diet containing vitamin $\mathrm{C}$ with the dose of $100 \mathrm{mg} /$ $\mathrm{kg}$ for 45 days then single doses of aminophylline $300 \mathrm{mg} /$ $\mathrm{kg}$ administered intraperitoneally to rats and subsequently put into individual perspex cages $(25 \times 25 \times 10 \mathrm{~cm})$. The rats were then observed as same way as Group I rats.

c) Group IIc - The rats ( $n=7)$ in the group were subjected to normal diet containing both vitamin C $(50 \mathrm{mg} / \mathrm{kg})$ with vitamin $E(20 \mathrm{mg} / \mathrm{kg})$ for 45 days then single doses of aminophylline $300 \mathrm{mg} / \mathrm{kg}$ administered intraperitoneally to rats and subsequently put into individual perspex cages $(25 \times 25 \times 10 \mathrm{~cm})$. The rats were then observed as same way as Group I rats. 
d) Group IId - The rats ( $n=7$ ) received a single injection of $0.9 \%$ saline at a dosage of $10 \mathrm{ml} / \mathrm{kg}$ via same route for 45 days then single doses of aminophylline $300 \mathrm{mg} / \mathrm{kg}$ administered intraperitoneally to rats and subsequently put into individual perspex cages $(25 \times 25 \times 10 \mathrm{~cm})$. The rats were then observed as same way as Group I rats and served as the control.

All the rats in this group then were sacrificed by cervical dislocation.

\section{Tissue sample preparation}

\section{A. Preparation of brain extract-}

To determine oxidative changes in different area of brain, rat brains were dissected and segregated in the following order cortex, cerebellum, midbrain and the basal ganglia. The brain tissues were mildly washed in normal saline to remove the blood and were frozen immediately after this, at first at $-20^{\circ} \mathrm{C}$ and then at $-70^{\circ} \mathrm{C}$, and kept under these conditions $\left(-70^{\circ} \mathrm{C}\right)$ until chemical analysis was performed. For homogenisation, samples were first washed and minced with sharp surgical blade in small volumes of ice cold (not frozen) homogenisation buffer made of $0.1 \mathrm{M}$ Tris- $\mathrm{HCl}$ (pH 7.35) and $100 \mu \mathrm{M}$ ethylenediaminetetraacetic acid (EDTA). Immediately the samples were homogenised in 10 volumes of the ice cool buffer solution in a motor driven glass tissue homogenizer in presence of properly washed few particles of sand. During the whole homogenisation procedure the homogeniser was kept submerged in small ice particles to dissipate any heat. Thereafter the samples were centrifuged at $10,000 \mathrm{rpm}$ for $10 \mathrm{~min}$ in a refrigerated cold centrifuge machine at $40 \mathrm{C}$. Supernatants from the homogenates were collected and were estimated for MDA, PC adducts, cytosolic superoxide dismutase $\left(\mathrm{Cu}^{2+}-\mathrm{Zn}^{2+}-\mathrm{SOD}\right)$ and tissue protein immediately.

\section{Biochemical assay}

MDA, a marker of lipid peroxidation due to oxidative stress was measured by its reaction with thiobarbituric acid at 532 $\mathrm{nm}$. The brain tissue levels of MDA were calculated using a calibration curve derived from 1,1,3,3-tetraethoxypropane (Fluka, Germany) as the external calibration standard. The calibration curve was linear in range from 1.25 to $2.5 \mathrm{nmol} /$ $\mathrm{ml}(\mathrm{r} 2=0.997) .{ }^{14}$ Oxidation induced changes in the tissue proteins were estimated by measuring the protein carbonyl (PC) products. The method is based on the reaction of carbonyl groups with 2,4- dinitrophenylhydrazine to form a 2,4- dinitrophenylhydrazone reactive carbonyl derivate that was measured at $370 \mathrm{~nm} \cdot{ }^{15}$ Estimation of cytosolic SOD was done by the method of Kakkar et al. Where one unit of SOD was defined as that amount of enzyme that inhibited the rate of electron transfer from reduced Nicotinamide adenine dinucleotide (NADH) to nitroblue tetrazolium (NBT) by $50 \%$ under specified conditions. ${ }^{16}$ Tissue proteins were measured by the method of Lowry et al. ${ }^{17}$ that involved reaction of proteins in tissue homogenates with alkaline copper sulphate followed by another reaction with
Folin's phenol reagent (SRL, India) against a standard curve prepared form bovine serum albumin (Merck, Germany). All photometric measurements were performed in Dual beam spectrophotometer (UV 5704SS). The parameters were expressed in their corresponding units per $\mathrm{mg}$ of tissue protein.

\section{Statistical analysis}

The data for biochemical analysis was subjected to standard statistical analysis using the Statistical Package for Social Science (SPSS) 11.5 software for windows.

Effects of aminophylline in inducing seizures on Group I rats and Effects of antioxidant vitamins on aminophyllineinduced seizures in Group II rats - Fisher's exact test were done by Fisher's exact test.

Then differences between the mean values of oxidative stress parameters in different area of brain of the aminophylline-treated rats and controls was carried out by using ANOVA with Bonferroni correction.

Differences between the mean values of oxidative stress parameters in different area of brain of the different groups of Group II rats was done by ANOVA with Bonferroni correction

For all tests, the $\mathrm{p}$-value was considered to be significant if it was less than 0.05 at a confidence level of $95 \%$.

\section{RESULTS}

\section{Effects of aminophylline in inducing seizures on Group I rats- Fisher's exact test}

At $100 \mathrm{mg} / \mathrm{kg}$ of aminophylline none of the rats in Group I showed convulsions or mortality. At higher doses of aminophylline $(200 \mathrm{mg} / \mathrm{kg}), 25 \%$ of rats showed clonic/ tonic-clonic convulsions and considerable $24 \mathrm{hr}$ postseizure mortality was observed. At a still higher dose (300 $\mathrm{mg} / \mathrm{kg}$ ) of the drug, all the animals (100\%) of the group exhibited tonic-clonic convulsions with $100 \%$ mortality within 1 hour of injection as shown in the Table 1.

Table 1. Effects aminophylline in inducing seizures on Group I rats

\begin{tabular}{|cccc|}
\hline Treatment (intraperitoneal) & $\begin{array}{c}\text { Incidence of } \\
\text { seizures }(\%)\end{array}$ & \multicolumn{2}{c|}{ Mortality (\%) } \\
\hline $\begin{array}{c}100 \mathrm{mg} / \mathrm{kg} \text { Aminophylline } \\
(\mathrm{n}=7)\end{array}$ & 0 & $30 \mathrm{~min}$ & 1 hour \\
\hline $\begin{array}{c}200 \mathrm{mg} / \mathrm{kg} \text { Aminophylline } \\
(\mathrm{n}=7)\end{array}$ & 28 & 0 & 0 \\
\hline $\begin{array}{c}300 \mathrm{mg} / \mathrm{kg} \text { Aminophylline } \\
(n=7)\end{array}$ & 100 & 57 & 100 \\
\hline
\end{tabular}

Accordingly, for subsequent experiments, the dose at 300 $\mathrm{mg} / \mathrm{kg}$ was selected for studying possible protective effects of chain breaking vitamin antioxidants vitamin $E$ and vitamin C against aminophylline seizures in Group II rats. 
Table 2. Effects of antioxidant vitamins on aminophylline-induced seizures in Group II rats

\begin{tabular}{|c|c|c|c|c|c|}
\hline $\begin{array}{l}\text { Treatment } \\
\text { (intraperitoneal) }\end{array}$ & $\begin{array}{l}\text { Group IId } \\
\text { (Control) } \\
n=7\end{array}$ & $\begin{array}{l}\text { Group } \\
\text { Ila } \\
(n=7)\end{array}$ & $\begin{array}{l}\text { Group } \\
\text { IIb } \\
(n=7)\end{array}$ & $\begin{array}{l}\text { Group } \\
\text { IIC } \\
(n=7)\end{array}$ & $\begin{array}{c}P \\
\text { value }\end{array}$ \\
\hline $\begin{array}{l}\text { Incidence of } \\
\text { seizures (\%) }\end{array}$ & 100 & 100 & 100 & 100 & $>0.05$ \\
\hline \multicolumn{6}{|l|}{ Mortality (\%) } \\
\hline $30 \mathrm{~min}$ & 71 & 86 & 71 & 86 & $>0.05$ \\
\hline 1 hour & 100 & 100 & 100 & 100 & $>0.05$ \\
\hline
\end{tabular}

$\mathrm{p}$ values were compared to Aminophylline $300 \mathrm{mg} / \mathrm{kg}$ group

Effects of antioxidant vitamins on aminophylline-induced seizures in Group II rats - Fisher's exact test

To analyzed the effects of antioxidant vitamins on aminophylline-induced seizures in Group II rats Fisher's exact test was performed and revealed that pretreatment with antioxidant, vitamin $\mathrm{E}$ at the dose of $20 \mathrm{mg} / \mathrm{kg}$ even at a higher dose $(40 \mathrm{mg} / \mathrm{kg}$ ) and Ascorbic acid at the dose of $50 \mathrm{mg} / \mathrm{kg}$ and $100 \mathrm{mg} / \mathrm{kg}$ administered for 45 days prior to aminophylline, showed no dose related antagonizing effects on seizurogenic effect of aminophylline ( $300 \mathrm{mg} / \mathrm{kg}$ ) and $24 \mathrm{hr}$ post-seizure mortality. Again when ascorbic acid $(10 \mathrm{mg} / \mathrm{kg})$ and vitamin $\mathrm{E}(20 \mathrm{mg} / \mathrm{kg})$ were given in the form of combination therapy no synergistic effects were evident, that means though they are well known antioxidant but they were ineffective in these regard as in the Table 2.

Differences between the mean values of oxidative stress parameters in different area of brain of the aminophyllinetreated rats and controls- ANOVA with Bonferroni correction

To analyze the differences between the mean values of oxidative stress parameters in different area of brain of the aminophylline-treated rats and controls ANOVA with Bonferroni correction was done and it was found that (Table
Table 3. ANOVA with Bonferroni correction showing multiple comparisons between study parameters with significance of difference, within different brain of the aminophylline-treated rats and controls.

\begin{tabular}{llll} 
Parameters & Sources & Control & $\begin{array}{l}\text { Aminophylline } \\
(300 \mathrm{mg} / \mathrm{kg})\end{array}$ \\
$\begin{array}{l}\text { Tissue MDA } \\
\text { (nmol/mg of } \\
\text { protein) }\end{array}$ & Cortex & $0.44 \pm 0.06$ & $0.92 \pm 0.08^{*}$ \\
& Midbrain & $0.34 \pm 0.04$ & $0.79 \pm 0.04^{*}$ \\
\hline & Basal ganglia & $0.44 \pm 0.07$ & $1.24 \pm 0.25^{*}$ \\
\hline $\begin{array}{l}\text { Tissue PC (mM/ } \\
\text { mg of protein) }\end{array}$ & Cerebellum & $0.3 \pm 0.08$ & $0.67 \pm 0.06^{*}$ \\
& Midbrain & $0.13 \pm 0.02$ & $0.31 \pm 0.0^{*}$ \\
& Basal ganglia & $0.11 \pm 0.02$ & $0.45 \pm 0.11^{*}$ \\
\hline $\begin{array}{l}\text { Cytosolic SOD } \\
\text { (IU/mg of pro- } \\
\text { tein) }\end{array}$ & Cortex & $0.55 \pm 0.08$ & $1.27 \pm 0.04^{*}$ \\
& Cerebellum & $0.56 \pm 0.07$ & $1.02 \pm 0.05^{*}$ \\
\hline & Midbrain & $0.39 \pm 0.09$ & $1.19 \pm 0.06^{*}$ \\
\hline & Basal ganglia & $0.56 \pm 0.07$ & $0.98 \pm 0.14^{*}$
\end{tabular}

3) MDA and PC product concentration were significantly higher in all area areas of the brain in the Aminophylline treated $(300 \mathrm{mg} / \mathrm{kg}$ ) rats than control rats At the same time the intracellular antioxidant enzyme, $\mathrm{Cu}^{2+}-\mathrm{Zn}^{2+}-\mathrm{SOD}$ activity was found to be significantly increased than controls.

Differences between the mean values of oxidative stress parameters in different area of brain of the different groups of Group II rats- ANOVA with Bonferroni correction

In Table 4, it is shown that MDA and PC product concentration were significantly higher in all area areas of the brain in the Aminophylline treated $(300 \mathrm{mg} / \mathrm{kg}$ ) rats than other rats that were pre-treated with antioxidants. At the same time the intracellular antioxidant enzyme, $\mathrm{Cu}^{2+}$ $\mathrm{Zn}^{2+}-\mathrm{SOD}$ activity was found to be significantly reduced by antioxidants than aminophylline treated rats.

Table 4. Multiple comparison between study parameters within different area of brain of the different groups of Group II rats-

\begin{tabular}{|c|c|c|c|c|c|}
\hline Parameters & Sources & $\begin{array}{l}\text { Aminophylline } \\
(300 \mathrm{mg} / \mathrm{kg})\end{array}$ & $\begin{array}{l}\text { Vitamin E }(40 \mathrm{mg} / \mathrm{kg} \\
\text { for } 45 \text { days })+ \text { Amino- } \\
\text { phylline }(300 \mathrm{mg} / \mathrm{kg})\end{array}$ & $\begin{array}{c}\text { Vitamin C (100mg/ } \\
\mathrm{kg})+ \text { Aminophylline } \\
(300 \mathrm{mg} / \mathrm{kg})\end{array}$ & $\begin{array}{l}\text { Vitamin E ( } 40 \mathrm{mg} / \mathrm{kg} \\
\text { for } 45 \text { days) + Vitamin } \\
\text { C ( } 100 \mathrm{mg} / \mathrm{kg})+ \text { Ami- } \\
\text { nophylline }(300 \mathrm{mg} / \mathrm{kg})\end{array}$ \\
\hline \multirow{4}{*}{ Tissue MDA (nmol/mg of protein) } & Cortex & $0.92 \pm 0.08$ & $0.57 \pm 0.04^{*}$ & $0.56 \pm 0.08^{*}$ & $0.49 \pm 0.03^{*}$ \\
\hline & Cerebellum & $0.67 \pm 0.06$ & $0.34 \pm 0.07 *$ & $0.38 \pm 0.07^{*}$ & $0.32 \pm 0.04 *$ \\
\hline & Midbrain & $0.79 \pm 0.04$ & $0.38 \pm 0.04 *$ & $0.42 \pm 0.02 *$ & $0.32 \pm 0.05^{*}$ \\
\hline & Basal ganglia & $1.24 \pm 0.25$ & $0.55 \pm 0.03 *$ & $0.53 \pm 0.08 *$ & $0.47 \pm 0.08^{*}$ \\
\hline \multirow{4}{*}{ Tissue PC (mM/mg of protein) } & Cortex & $0.31 \pm 0.02$ & $0.17 \pm 0.03 *$ & $0.16 \pm 0.07^{*}$ & $0.16 \pm 0.02^{*}$ \\
\hline & Cerebellum & $0.26 \pm 0.03$ & $0.10 \pm 0.03 *$ & $0.13 \pm 0.01 *$ & $0.11 \pm 0.02 *$ \\
\hline & Midbrain & $0.28 \pm 0.02$ & $0.23 \pm 0.05 *$ & $0.22 \pm 0.04 *$ & $0.19 \pm 0.03 *$ \\
\hline & Basal ganglia & $0.45 \pm 0.11$ & $0.14 \pm 0.03 *$ & $0.14 \pm 0.01 *$ & $0.16 \pm 0.03 *$ \\
\hline \multirow{4}{*}{ Cytosolic SOD (IU/mg of protein) } & Cortex & $1.27 \pm 0.04$ & $0.64 \pm 0.05 *$ & $0.55 \pm 0.09 *$ & $0.59 \pm 0.06^{*}$ \\
\hline & Cerebellum & $1.02 \pm 0.05$ & $0.56 \pm 0.11 *$ & $0.58 \pm 0.06^{*}$ & $0.61 \pm 0.03 *$ \\
\hline & Midbrain & $1.19 \pm 0.06$ & $0.44 \pm 0.23 *$ & $0.48 \pm 0.05^{*}$ & $0.45 \pm 0.06 *$ \\
\hline & Basal ganglia & $0.98 \pm 0.14$ & $0.69 \pm 0.17 *$ & $0.67 \pm 0.06^{*}$ & $0.71 \pm 0.12^{*}$ \\
\hline
\end{tabular}

$* p<0.05$ compared to Aminophylline $300 \mathrm{mg} / \mathrm{kg}$ group (Control group); Values are mean \pm SD 


\section{DISCUSSION}

The therapeutic use of aminophylline is associated with the incidence of intractable seizures and mortality. ${ }^{2,18}$ Despite a long clinical history of aminophylline-induced seizures, relatively little is known about the underlying molecular mechanisms that contribute to methylxanthine-induced seizure generation. Free radicals have considerable neurotoxic potential and the present study evaluated the possible involvement of these bioactive moieties in aminophylline-induced seizures in mice and some results were found in the present study.

At first that aminophylline administered in high doses of $300 \mathrm{mg} / \mathrm{kg}$ consistently induced seizures in all rats, an effect that was not seen at lower doses $(100 \mathrm{mg} / \mathrm{kg})$ of the drug. So, aminophylline induced clonic/tonic-clonic seizures in a dose-dependent manner and this is in agreement with earlier reports in this regard. .,10,19 $^{5}$

Though aminophylline has got antioxidant property the present study it was also found that it generate sufficient amount of free radicals.

Both exogenous and endogenous antioxidants are known to protect against oxidative injury caused by free radical generation. Ascorbic acid and vitamin E are nutraceuticals with considerable antioxidant potential and their use as protectants from free radical induced damage has been widely suggested. So, in the present study pre-treatment with antioxidants, though vitamin $\mathrm{E}(20 \mathrm{mg} / \mathrm{kg})$ and vitamin

\section{REFERENCES}

1. Kaptanoglu E, Solaroglu I, Akbiyik F,Demirpence E, Ergungor MF. The Antioxidant Effect of Aminophylline in Rat Brain and Spinal Cord Homogenates. Turkish Neurosurgery 2003;13:9-13.

2. Farooque M. Spinal cord compression injury in the mouse: presentation of a model including assessment of motor dysfunction. Acta Neuropathol. 2000;100(1):13-22.

3. Gautam MS, John J, Rout P, Thennarusu K, Nehlig A, Kulkarni C. Protective effects of graded doses of Gabapentin on Aminophyllineinduced experimental status epilepticus in mice. Annals of Neurosciences 2009;16(4): doi: 10.5214/ans.0972.7531.2009.160404

4. Gupta YK, Malhotra J. Influence of adenosine agonists and antiepileptic drugs on theophylline-induced seizures in rats. Indian J Physiol Pharmacol 1998;42(4):491-7.

5. Mirhadi K ,Seiedrazi B. Effect of Nimodipine on Dichlorvos-Induced Seizure in Mice. American-Eurasian Journal of Toxicological Sciences 2011;3(3): 204-7.

6. Sarma AD, Mallick AR, Ghosh AK. Free Radicals and Their Role in Different Clinical Conditions: An Overview. International Journal of Pharma Sciences and Research 2010;1(3):185-92.

7. Lebel $\mathrm{CP}$, Bondy SC. Oxygen radicals: Common mediators of neurotoxicity. Neurotoxicol. Teratol. 1991; 13: 341.

8. Saeed SA, Shad KF, Saleem T, Javed F, Khan MU. Some new prospects in the understanding of the molecular basis of the pathogenesis of stroke. Exp Brain Res Exp Hirnforsch Exp Cerebr 2007;182:1-10.

9. Ray A, Gulati K, Anand S, Vijayan VK. Pharmacological studies on mechanisms of aminophylline-induced seizures in rats. Indian Journal of Experimental Biology 2005;43: 849-53.
C $(50 \mathrm{mg} / \mathrm{kg})$ can effectively reduce the oxidative stress that was caused by aminophylline but they were very much ineffective in antagonizing aminophylline $(300 \mathrm{mg} /$ $\mathrm{kg}$ ) induced seizures and $24 \mathrm{hr}$ post-seizure mortality by any appreciable extent. Moreover, combined treatment of vitamin E $(40 \mathrm{mg} / \mathrm{kg})$ with the vitamin C $(100 \mathrm{mg} / \mathrm{kg})$ prior to aminophylline $(300 \mathrm{mg} / \mathrm{kg})$ did not exhibit any attenuating effects on aminophylline seizures and postseizure mortality. But in several previous studies have opposed our research observation and they have found that there have got possible involvement of oxidative stress during aminophylline-induced seizures as ascorbic acid as well as vitamin $\mathrm{E}$ attenuated aminophylline seizures. ${ }^{10,20,21}$ So, as pre-treatment with antioxidant is ineffective to prevent aminophylline induced seizure there is doubt about oxidative stress as an only aetiology in generation of this type of convulsion. There might be other possible causes and free radical generation may be partly along with it. As adenosine is known to act as a neuromodulator and has been widely reported as an endogenous anticonvulsant, $22-24$ adenosine antagonism and phosphodiesterase enzyme inhibition of aminophylline may be the explanation of aminophylline induced seizure.

\section{CONCLUSION}

The results are suggestive that at least free radicals are not only cause of convulsiogenic effects and post-seizure mortality of aminophylline.

10. Gillissen A, Wickenburg D, van Zwoll D, Schultze Werninghaus G. Beta-2-agonists have antioxidant function in vitro. 2. The effect of B2 agonists on oxidant-mediated cytotoxycity and on superoxide anion generated by human polymorphonuclear leucocytes. Respiration 1997;64(1): 23-8.

11. Mahomed AG, Theron AJ, Anderson R, Feldman C. Anti-oxidative effects of theophylline on human neutrophils involve cyclic nucleotides and protein kinase A. Inflammation 1998;22(6):545-557.

12. Isoni CA, Borges ÉA, Veloso CA, Mattos RT, Chaves MM, NogueiraMachado JA. CAMP activates the generation of reactive oxygen species and inhibits the secretion of IL- 6 in peripheral blood mononuclear cells from type 2 diabetic patients. Oxid Med Cell Longev. 2009 NovDec; 2(5): 317-321.doi: 10.4161/oxim.2.5.9657

13. Zwicker K, Damerau W, Dikalow S, Scholtyssek H, Schimke I, Zimmer G. Superoxyde radical scavenging by phenolic broncodilatators under aprotic and aqueous conditions. Biochem Pharmacol 1998;56:301305.

14. Dahle LK, Hill EG, Holman RT. The thiobarbituric acid reaction and the autoxidations of polyunsaturated fatty acid methyl esters. Arch Biochem Biophys 1962;98:253-61.

15. Levine RL, Garland D, Oliver CN, Amici A, Climent I, Lenz AGet al. Determination of carbonyl content in oxidatively modified proteins. Methods Enzymol 1990;186:464-78.

16. Kakkar P, Das B, Viswanathan PN. A modified spectrophotometric assay of superoxide dismutase. Indian J Biochem Biophys 1984;21:130-2.

17. Lowry OH, Rosebrough NJ, Farr AL, Randall RJ. Protein measurement with the Folin phenol reagent. J Biol Chem 1951;193:265-75. 
18. Barnes PJ, Pauwels RA. Theophylline in the management of asthma: Time for reappraisal. Eur. Respir. J 1995; 7: 579.

19. Nakada T, Kwee IL, Lerner AM, Remler MP. Theophylline induced seizures: Clinical and pathophysiological aspects. West J Med 1983; 138:371.

20. Gulati K, Ray A, Vijayan VK. Free radicals and theophylline neurotoxicity: an experimental study. Cell Mol Biol 2007;53(5):42-52.

21. Gulati K, Ray A, Pal G, Vijayan VK. Possible role of free radicals in theophylline-induced seizures in mice Pharmacology. Biochemistry and Behavior 2005; 82(1): 241-5.
22. Lovatt D, Xu Q, Liu W, Takano T, Smith NA, Schnermann J et al. Neuronal Adenosine Release, and not Astrocytic ATP Release, Mediates Feedback Inhibition of Excitatory Activity. Proc Natl Acad Sci USA 2012;109:6265-70.

23. Ilie A, Raimondo JV, Akerman CJ. Adenosine Release During Seizures Attenuates GABAA Receptor-Mediated Depolarization. J Neurosci 2012;32:5321-32.

24. Hargus NJ, Jennings C, Perez-Reyes E, Bertram EH, Patel MK. Enhanced actions of adenosine in medial entorhinal cortex layer II stellate neurons in temporal lobe epilepsy are mediated via A1-receptor activation. Epilepsia, 53(1):168-176, 2012doi: 10.1111/j.15281167.2011.03337. 